Primljen / Received: 30.5.2014. Ispravljen / Corrected: 20.7.2014.

Prihvaćen / Accepted: 10.8.2014.

Dostupno online / Available online: 10.10.2014.

\section{European soil classification system for engineering purposes}

Authors:

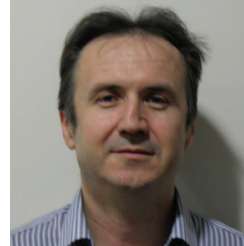

Prof. Meho Saša Kovačević, PhD. CE University of Zagreb

Faculty of Civil Engineering

Department for Geotechnical Engineering msk@grad.hr

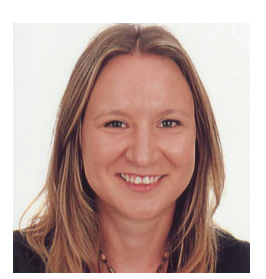

Assist.Prof. Danijela Jurić-Kaćunić, PhD. CE University of Zagreb

Faculty of Civil Engineering

Department for Geotechnical Engineering djk@grad.hr

\section{Meho Saša Kovačević, Danijela Jurić-Kaćunić}

\section{European soil classification system for engineering purposes}

This paper proposes the new European Soil Classification System (ESCS) for engineering purposes which uses soil description and symbols according to European standard EN ISO 14688-.1, and which 34 countries are bound to implement, as CEN members. ESCS is developed on principles for soil classification according to the European standard EN ISO 14688-.2, and it generally complies with guidelines defined by the USCS soil classification system in accordance with the US standard ASTM D 2487. The procedure for the use of proposed classification, and examples of comparison with the USCS classification system, are presented.

\section{Key words:}

soil classification, engineering, standard, particle size distribution, plasticity

Prethodno priopćenje

Meho Saša Kovačević, Danijela Jurić-Kaćunić

\section{Europska klasifikacija tla za inženjerske potrebe}

U radu se predlaže nova europska klasifikacija tla(ESCS) za inženjerske potrebe koja koristi opisi simbole označavanja tla prema europskoj normi EN ISO 14688-1, a koju su se, kao članice CEN-a, obvezale implementirati 34 europske zemlje. ESCS je razvijena na načelima klasifikacije tla prema europskoj normi EN ISO 14688-2 i okvirno slijedi smjernice definirane USCS klasifikacijom prema američkoj normi ASTM D 2487. Prikazana je procedura za provedbu predložene klasifikacije i dani su primjeri usporedbe rezultata klasificiranja tla sa USCS klasifikacijom.

Ključne riječi:

klasifikacija tla, inženjerstvo, norma, granulometrijski sastav tla, plastičnost

Vorherige Mitteilung

Meho Saša Kovačević, Danijela Jurić-Kaćunić

\section{Europäische Bodenklassifizierung für den Ingenieurbedarf}

In dieser Arbeit wird eine neue europäische Bodenklassifizierung (ESCS) für den Ingenieurbedarf vorgeschlagen, bei der Beschreibungen und Symbole zur Kennzeichnung von Böden nach der europäischen Norm EN ISO 14688-1 angenommen werden, die in 34 europäischen CEN-Mitgliedstaaten implementiert werden muss. Die ESCS ist im Einklang mit der europäischen Norm EN ISO 14688-2 und den entsprechenden Grundsätzen der Bodenklassifizierung entwickelt und folgt annähernd den Richtlinien der USCS Klassifizierung gemäß der amerikanischen Norm ASTM D 2487. Die Anwendung des vorgeschlagenen Verfahrens ist dargestellt und Beispiele der Bodenklassifizierung im Vergleich zur USCS Klassifizierung sind gegeben. 


\section{Introduction}

Soil classification is a set of procedures by which a great number of different soil types existing in nature are classified into groups of similar mechanical properties and behaviours in response to the influence of load. Placing a soil that is being tested into a particular predefined group makes it easier for engineers all over the world to study and understand soil test results, and to communicate with one another, and compare results obtained in different laboratories. Classification enables rough identification of the type of material, and definition of the range in which its mechanical properties are expected to vary.

Initial efforts to classify soil for engineering applications are strictly related to the classification according to the size of grains, i.e. according to the grain size composition of soil [1]. Such systems were based on soil texture i.e. on relative proportions of sand, silt and clay in the total mass of soil tested. Texture-based classifications of soil were first investigated in detail by Atterberg in the early $20^{\text {th }}$ century $[2,3]$. The best known classification based on texture is the classification developed by the USDA (US Department of Agriculture) in 1938. This classification was modified on several occasions since its initial appearance [4]. It is based on the use of a triangular classification diagram [5]. This classification is nowadays more used in agriculture than in geotechnical engineering. Atterberg pointed out in his papers that textural classifications of soil can successfully be used in agriculture, but that some other clay and silt parameters must also be considered when this classification is used in geotechnical applications.

Arthur Casagrande developed the ACS classification (Airfield Classification System) for the design of the US airfields during the Second World War [6]. This classification is based on the grain size distribution and consistence of coherent soil particles. The modification of the ACS classification resulted in 1952 in the creation of the USCS (unified Soil Classification System) soil classification, which is an integral part of the US standards ASTM D 2487-11 [7]. The adjustment of the ACS classification to mechanical properties of soil prevailing in the UK led in 1981 to the creation of the BSCS (British Soil Classification System) [8, 9] which is an integral part of British standards BS 5930:1999 [10]. The soil classification was similarly developed in 1988 by DIN (Deutsches Institut für Normung), and this classification is an integral part of German standards DIN 18196:2011-05 [11].

Most European countries used for many years some of the above mentioned soil classifications, or developed their own modified versions, depending on local soil conditions. In order to increase the quality, safety, reliability, efficiency, compatibility, and communication between experts in the field of geotechnics, the ISO (International Standards Organisation) and CEN (Comité Européen de Normalisation), developed standards for the description and identification of soil, and also defined soil classification principles which greatly differ, by the soil marking method, from the previously used national classification systems. In 2002, Technical Committee ISO/TC 182 "Geotechnics", in cooperation with Technical Committee CEN/TC 341 "Geotechnical Investigation and Testing", prepared the soil description standard entitled: Geotechnical investigation and testing - Identification and Classification of Soil - Part 1: Identification and description (EN ISO 14688-1:2002) [12]. An amendment to this standard was adopted in 2013 (EN ISO 14688-1:2002/A1:2013) [13]. In 2004, the same committee prepared the standard on soil classification principles, which is entitled: Geotechnical investigation and testing - Identification and classification of soil - Part 2: Principles for a classification (EN ISO 14688-2:2004) [14]. An amendment to this standard was adopted in 2013 (EN ISO 14688-1:2004/A1:2013) [15].

European countries that have accepted, as CEN members, to adopt and implement European standards through their national standardisation bodies are: Austria, Belgium, Bulgaria, Cyprus, Czech Republic, Denmark, Estonia, Finland, France, Greece, Croatia, Ireland, Iceland, Italy, Latvia, Lithuania, Luxemburg, Hungary, Macedonia, Malta, the Netherlands, Norway, Germany, Poland, Portugal, Romania, Slovakia, Slovenia, Spain, Sweden, Switzerland, Turkey, and Great Britain.

Upon proposal by the Technical Committee HZN/TO 182/PO 2, "Geotechnical Structures", the Croatian Standards Institute accepted in 2008 European standards EN ISO 14688-1:2002 and EN ISO 14688-2:2004 in their original English version as Croatian standards designated HRN EN ISO 14688-1:2008 [16] and HRN EN ISO 14688-2:2008 [17]. The amendments to these standards were accepted upon proposal by the same Committee, and so the currently applicable standards in Croatia are designated as HRN EN ISO 14688-1:2008/A1:2013 en [18], and HRN EN ISO 146882:2008/A1:2013 en [19].

Some older versions of the USCS soli classification, adjusted to the adopted European sieve aperture standards, were in use in Croatia until acceptance of European soil identification and classification standards. The acceptance of European standards did not result in either sudden or gradual transition to the new way of describing, indentifying, and classifying soil. This situation is due to some subjective and objective reasons. Subjective reasons lie in difficulties to accept new way of soil marking (e.g. silt is not marked as $\mathrm{M}$ but as Si) and in extensive local presence and availability of the US books and journals which leads to dominant use of the USCS classification. Objective reasons lie in the fact that European standards provide classification principles, rather than the full classification of soil. The possibility is left to develop a more complete classification on the national or project level based on these principles. In this situation, practical engineers are not able to conduct the soil classification in accordance with the European standard, which results in continued use of some of the earlier adopted national standards. In order to overcome these subjective and objective obstacles, the authors of the paper propose a comprehensive European soil classification ESCS (European Soil Classification System) that has been developed on the principles given in the European standard, and is generally compliant with guidelines defined in the USCS classification. The procedure for using the ESCS classification is presented, and examples for comparing soil classification results with the USCS classification are given. 


\section{USCS soil classification according to ASTM D 2487}

According to the USCS classification, soil is divided into: coarsegrained soil, fine-grained soil, and highly organic soil. The particle size distribution of soil and consistence limits are used in soil classification.

The basic idea of this classification relies on marking the soil with symbols that consist of two letters. The exceptions are cases when the soil is marked with double symbols consisting of four letters.

The first letter for the symbol for coarse-grained soil denotes the main type of soil:

$\mathrm{G}$ - gravel

$\mathrm{S}$ - sand

The second letter in the coarse-grained soil symbol describes characteristics of the main group:

W - well graded sand or gravel,

$P$ - poorly graded sand or gravel,

M - silty sand or gravel,

C - clayey sand or gravel.

The first letter in the symbol for fine-grained soil denotes the main type of soil:

$\mathrm{M}$ - silt (mjala in Swedish, silt in English),

C - clay,

O - organic soil.

The second letter in the fine-grained soil symbol describes characteristics of the main group:
L - low plasticity, lean for clay,

$\mathrm{H}$ - high plasticity, fat for clay, elastic for silt

Highly organic soil has a two-letter symbol for the main group of soil:

PT - peat.

The USCS classification of soil is presented in Table 1. In addition to Table 1, the plasticity diagram presented in Figure 1 is also used for soil classification.

\subsection{Procedure for USCS classification of soil according to ASTM D 2487}

\subsubsection{Procedure for preliminary classification of soil}

1. The soil is classified as coarse-grained (incoherent soil) if more than $50 \%$ of the total quantity of dry sample is retained on the sieve No. $200-0.075 \mathrm{~mm}$.

2. The soil is classified as fine-grained (coherent soil) if more than $50 \%$ of the total quantity of dry sample passes through the sieve No. $200-0.075 \mathrm{~mm}$.

\subsubsection{Procedure for classification of coarse-grained soil}

3. The soil is classified as gravel if more than $50 \%$ of material from the total dry sample mass is retained on the sieve No. $4-4.75 \mathrm{~mm}$ (including the sieve No. $200-0.075 \mathrm{~mm}$ ).

4. The soil is classified as sand if more than $50 \%$ of material from the total dry sample mass passes through the sieve No. $4-4.75$ mm (including the sieve No. $200-0.075$ $\mathrm{mm})$.

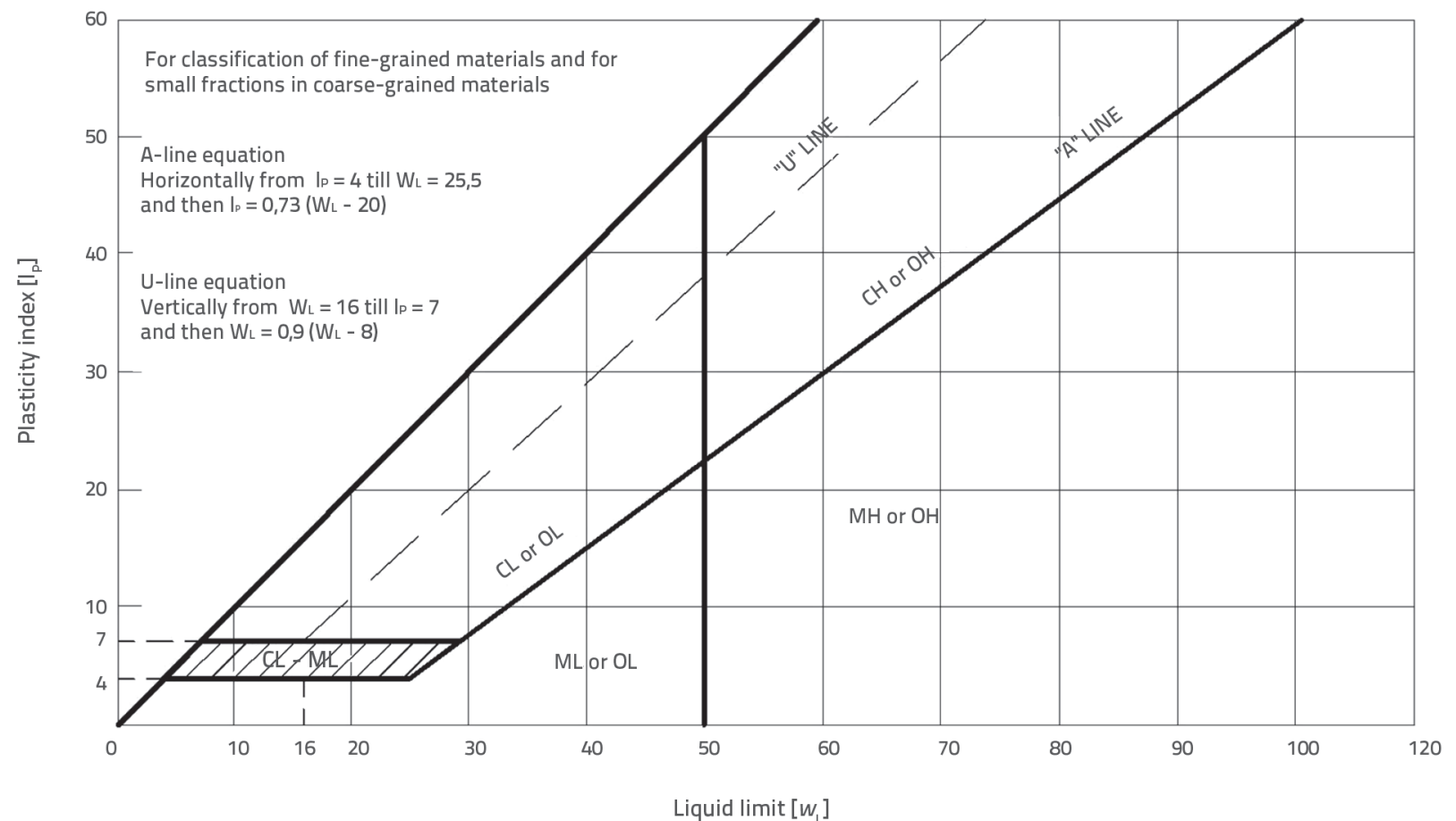

Figure 1. Plasticity diagram for the USCS classification according to ASTM D 2487 
Table 1. USCS classification of soil according to ASTM D 2487

\begin{tabular}{|c|c|c|c|c|c|}
\hline \multirow{2}{*}{\multicolumn{4}{|c|}{ Criteria for allocation of symbols and names to individual soil groups based on laboratory testing ${ }^{\mathrm{A}}$}} & \multicolumn{2}{|c|}{ Soil classification } \\
\hline & & & & Symbol & Group name ${ }^{B}$ \\
\hline \multirow{8}{*}{ 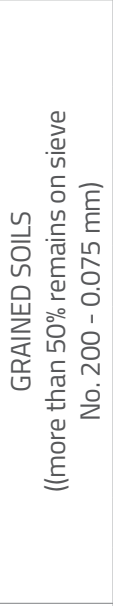 } & \multirow{4}{*}{ 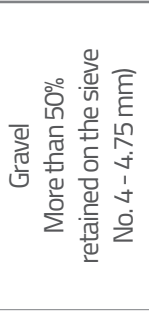 } & \multirow{2}{*}{$\begin{array}{l}\text { Pure gravel } \\
\text { (less than } 5 \% \text { of fine grains }{ }^{⿷} \text { ) }\end{array}$} & $\begin{array}{l}c_{u} \geq 4 \text { and } \\
1 \leq c_{c} \leq 3^{c}\end{array}$ & GW & Well graded gravel ${ }^{\mathrm{D}}$ \\
\hline & & & $\begin{array}{c}c_{u}<4 \text { and } / o r \\
1>c_{c}>3^{c}\end{array}$ & $\mathrm{GP}$ & Poorly graded gravel ${ }^{\mathrm{D}}$ \\
\hline & & \multirow{2}{*}{$\begin{array}{l}\text { Gravel with fine grains } \\
\text { (more than } 12 \% \text { of fine grains }\end{array}$} & Fine grains are classified as $\mathrm{ML}$ or $\mathrm{MH}$ & GM & Silty gravel $\left.\right|^{D, F, G}$ \\
\hline & & & Fine grains are classified as $\mathrm{CL}$ or $\mathrm{CH}$ & GC & Clayey gravel ${ }^{D, F, G}$ \\
\hline & \multirow{4}{*}{ 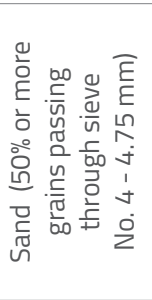 } & \multirow{2}{*}{$\begin{array}{l}\text { Pure sand } \\
\text { (less than } 5 \% \text { of fine particles') }\end{array}$} & $\begin{array}{l}c_{u} \geq 6 \text { and } \\
1 \leq c_{c} \leq 3^{c}\end{array}$ & SW & Well graded sand ${ }^{\mathrm{H}}$ \\
\hline & & & $\begin{array}{c}c_{u}<6 \text { and } 7 \text { or } \\
1>c_{c}>3^{c}\end{array}$ & SP & Poorly graded sand ${ }^{H}$ \\
\hline & & \multirow{2}{*}{$\begin{array}{l}\text { Sand with fine grains } \\
\text { (more than } 12 \% \text { of fine grains') }\end{array}$} & Fine grains are classified as ML or $\mathrm{MH}$ & SM & Silty sand ${ }^{F, G, H}$ \\
\hline & & & Fine grains are classified as $\mathrm{CL}$ or $\mathrm{CH}$ & $\mathrm{SC}$ & Clayey sandF,G,H \\
\hline \multirow{8}{*}{ 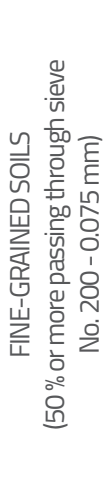 } & \multirow{4}{*}{ 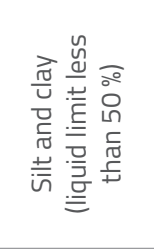 } & \multirow{4}{*}{ Inorganic } & $I_{\mathrm{P}}>7$ and at or above $\mathrm{A}$-line & $\mathrm{CL}$ & Posna glina $a^{K, L, M}$ \\
\hline & & & $I_{\mathrm{p}}<4$ or below A-line & $\mathrm{ML}$ & Silt ${ }^{K, L, M}$ \\
\hline & & & \multirow{2}{*}{$\begin{array}{l}\text { (Liquid limit - drying in oven) / } \\
\text { (Liquid limit - without drying in oven) < } 0.75\end{array}$} & \multirow{2}{*}{$\mathrm{OL}$} & Organic clay ${ }^{K, L, M, N}$ \\
\hline & & & & & Organic silt ${ }^{K, L, M, O}$ \\
\hline & \multirow{4}{*}{ 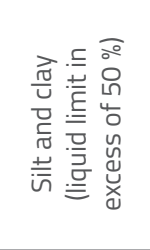 } & \multirow{2}{*}{ Inorganic } & $I_{\mathrm{P}}$ na ili iznad A-linije & $\mathrm{CH}$ & Fat clay ${ }^{K, L, M}$ \\
\hline & & & $I_{\mathrm{P}}$ ispod A-linije & $\mathrm{MH}$ & Elastic silt ${ }^{K, L, M}$ \\
\hline & & \multirow{2}{*}{ Organic } & \multirow{2}{*}{$\begin{array}{l}\text { (Liquid limit - drying in oven) / } \\
\text { (Liquid limit - without drying in oven) < } 0.75\end{array}$} & \multirow{2}{*}{$\mathrm{OH}$} & Organic clay ${ }^{K, L, M, P}$ \\
\hline & & & & & Organic silt ${ }^{K, L, M, Q}$ \\
\hline \multicolumn{2}{|c|}{ Highly organic soil } & \multicolumn{2}{|c|}{ Primary organic matter, dark in colour, with organic odour } & PT & Peat \\
\hline \multicolumn{6}{|c|}{ 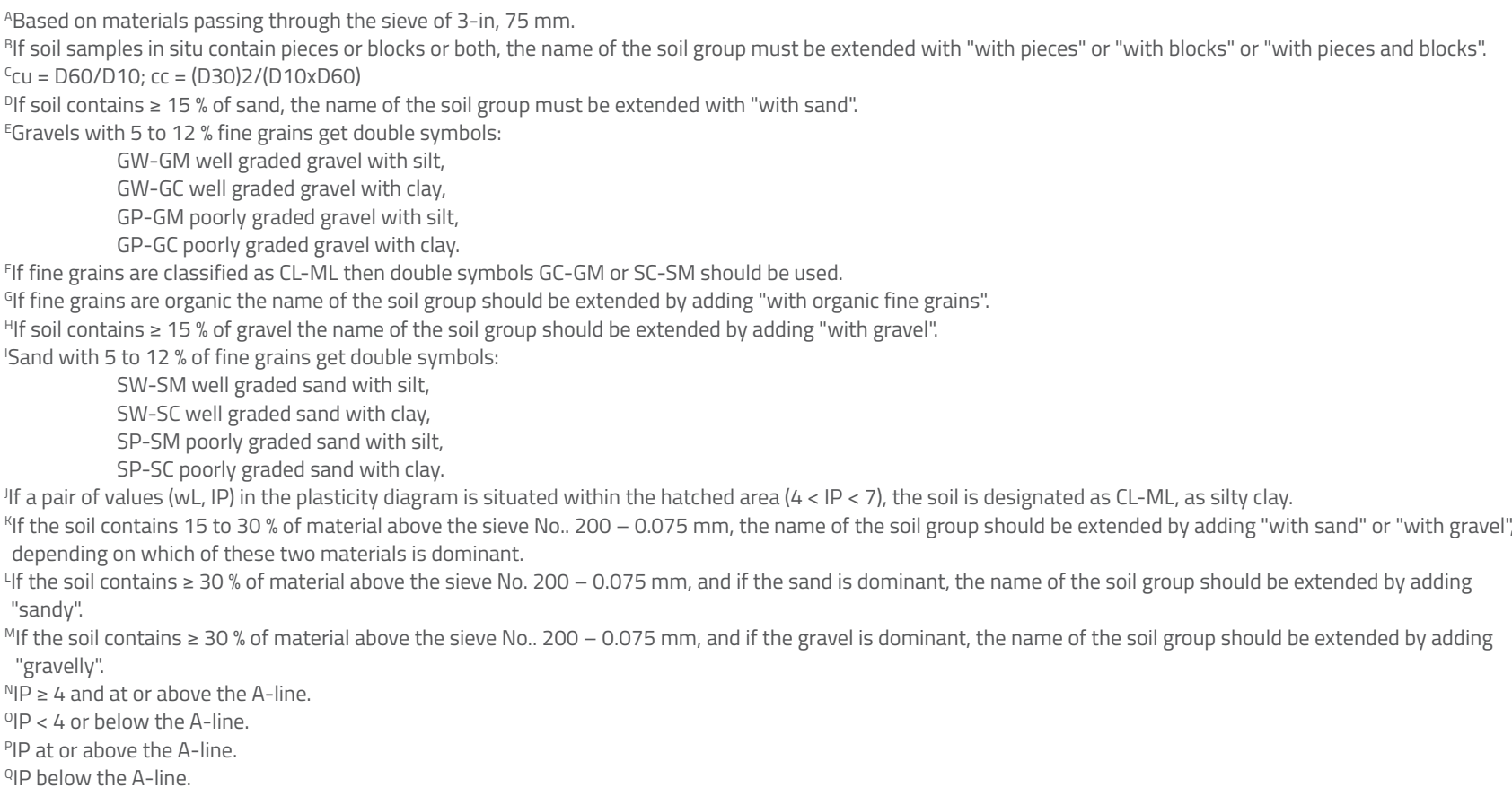 } \\
\hline
\end{tabular}


5. If less than $5 \%$ of the sample mass passes through the sieve No. $200-0.075 \mathrm{~mm}$ then the grading curve should be used to calculate the uniformity coefficient $c_{u}$ and the curvature coefficient $c$.

5.1 If the coefficient of uniformity $c_{u}$ is equal to or greater than 4 for gravel, or equal to or greater than 6 for sand, and if the curvature coefficient is equal to 1 and not greater than 3, the soil is classified as the well graded gravel, GW, or as the well graded sand, SW.

5.2 If coefficients of uniformity and curvature do not meet criteria for well graded soil, the soil is classified as a poorly graded gravel, GP, or as a poorly graded sand, SP.

6. If more than $12 \%$ of the sample mass passes through the sieve No. $200-0.075 \mathrm{~mm}$, the soil is considered to be a coarse-grained material with fine grains. At that, it should be established whether fine grains are clay or silt, which is determined from the plasticity diagram using the plasticity index and liquid limit.

6.1 The soil is classified as clayey gravel, GC, or clayey sand, $\mathrm{SC}$, if the pair of values $\left(w_{L^{\prime}} I_{p}\right)$ in the plasticity diagram is situated above the $A$ line and if $I_{p}$ is greater than 7 .

6.2 The soil is classified as silty gravel, GM, or silty sand, SM, if the pair of values $\left(w_{L^{\prime}} I_{p}\right)$ in the plasticity diagram is situated below the $A$ line and if $I_{P}$ is smaller than 4 .

6.3 if the pair of values $\left(w_{L^{\prime}} I_{p}\right)$ in the plasticity diagram is situated in the $\mathrm{CL}-\mathrm{ML}$ range, and if the $I_{p}$ is greater than 4 and smaller than 7, the soil is classified as silty clayey gravel, SC-SM, in case of sand.

7. If 5 to $12 \%$ of fine soil grains pass through the sieve No. $200-0.075$, then double symbols are attributed to the soil. The coefficient of uniformity, $c_{u^{\prime}}$ and the coefficient of curvature, $c_{c^{\prime}}$ must be calculated from the grading curve. At that, it should be established whether fine grains are clay or silt particles, which is determined from the plasticity diagram using the plasticity index and liquid limit.

7.1 The first group of symbols coincides with the group in which the gravel or sand have less than $5 \%$ of fine grains (GW, GP, SW, SP), and the second group of symbols coincides with the group in which the gravel or sand have more than $12 \%$ of small grains (GC, GM, SC, SM).

7.2 The group symbol coincides with the first group but it is extended by adding "with clay" or "with silt", which denotes plastic properties of fine grains. For instance, well graded gravel with clay, GP-GC, poorly graded sand with silt, SP-SM.

8. If the sand or gravel is dominant in the total mass of the soil sample, and if it contains $15 \%$ or more of some other coarse-grained material, then the group symbol is extended by adding "with gravel" or "with sand". For instance, poorly graded gravel with sand, GP, clayey sand with gravel, SC.

9. If the soil sample in situ contains pieces or blocks or both pieces and blocks, the group symbol is extended by adding "with pieces" or "with blocks" or "with pieces and blocks". For instance, silty gravel with pieces, GM. The same is valid for fine-grained materials.

\subsubsection{Procedure for classification of fine-grained soil}

10. The soil is considered to be an inorganic clay if the pair of values $\left(w_{L^{\prime}} I_{p}\right)$ in the plasticity diagram is situated at or above the $A$ line, the index of plasticity is greater than 4 , and the presence of inorganic material does not influence determination of liquid limit according to Section 12.2.

10.1 The soil is classified as lean clay, $C L$, if the liquid limit is smaller than $50 \%$.

10.2 The soil is classified as fat clay, $\mathrm{CH}$, if the liquid limit is greater than $50 \%$.

10.3 The soil is classified as silty clay, CL-ML, if the pair of values $\left(w_{L^{\prime}} I_{p}\right)$ is situated at or above the $A$ line, and the value of the index of plasticity ranges from 4 to 7 .

11. The soil is considered to be an inorganic silt is the pair of values $\left(w_{L}, I_{p}\right)$ in the plasticity diagram is situated below the $A$ line or the plasticity index is smaller than 4, and the presence of organic material does not influence determination of liquid limit according to Section 12.2.

11.1 The soil is classified as silt, ML, if the liquid limit is smaller than $50 \%$.

11.2 The soil is classified as elastic silt, $\mathrm{MH}$, if the liquid limit is greater than $50 \%$.

12. The soil is considered to be an organic clay or silt if organic matter is present in the quantity that is considered sufficient to influence determination of liquid limit according to Section 12.2.

12.1 If the soil is dark in colour and if it has an organic smell when moist or warm, then the second liquid limit is tested on the sample dried overnight in oven at 110 $\pm 5^{\circ} \mathrm{C}$ until constant weight.

12.2 The soil is organic silt or organic clay if the liquid limit after drying in oven is lower that $75 \%$ of the liquid limit of the original sample determined prior to drying in oven.

12.3 The soil is classified as organic clay or organic silt, $\mathrm{OL}$, if the liquid limit (without drying in oven) is lower than 50 $\%$. The soil is classified as organic silt if the pair of values $\left(w_{L^{\prime}} I_{p}\right)$ is situated below the A line, and the plasticity index is smaller than 4 . The soil is classified as organic clay if the pair of values $\left(w_{L^{\prime}} I_{p}\right)$ is situated at or above the $A$ line, and the plasticity index is greater than 4 .

12.4 The soil is classified as organic clay or organic silt, $\mathrm{OH}$, if the liquid limit (without drying in oven) is higher than $50 \%$. The soil is classified as organic silt if the pair of values $\left(w_{L^{\prime}} I_{p}\right)$ is situated below the $A$ line. The soil is classified as organic clay if the pair of values $\left(w_{L^{\prime}} I_{p}\right)$ is situated at or above the $\mathrm{A}$ line.

13. If more than $15 \%$ but less than $30 \%$ of the coarse-grained material from the total quantity of samples is retained on the sieve No. $200-0.075 \mathrm{~mm}$, then the group symbol is extended by adding "with gravel" or "with sand" (depending on the dominant material). For instance, lean clay with sand, $C L$, silt with gravel, ML. If the same quantity of gravel and sand is present, the advantage is given to the sand and the wording "with sand" is added. 
14. If $30 \%$ or more of the total quantity of sample is retained at the sieve No. $200-0.075 \mathrm{~mm}$, then the group symbol is extended by adding "sandy" or "gravelly". The wording "sandy" is used when $30 \%$ or more to the sample tested is retained at the sieve No. $200-0.075 \mathrm{~mm}$, and sand is the dominant coarse-grained material. The wording "gravelly" is used when $30 \%$ or more of the sample tested is retained at the sieve No. $200-0.075 \mathrm{~m}$, and gravel is the dominant coarse-grained material. For instance, sandy lean clay, $\mathrm{CL}_{\text {; }}$ gravelly fat clay, $\mathrm{CH}$, sandy silt, ML. If the same quantity of gravel and sand is present, the advantage is given to the sand and the wording "sandy" is used.

\section{ESCS soil classification according to principles given in EN ISO 14688-2}

According to the proposed ESCS classification, the soil is divided into: coarse-grained soil, fine-grained soil, and organic soil. The soil grading and consistence limits are used in soil classification. In this classification, the main idea is to mark soil with symbols representing principal and secondary fractions out of which the soil is made. The principal fraction of soil determines engineering properties of soil. Secondary fractions do not determine, but they do influence, engineering properties of soil.

The principal fraction of coarse-grained soils is marked with symbols composed of two letters, out of which the first one is written with capital letter:
Gr - gravel,

Sa - sand.

The secondary fraction that mostly influences engineering properties of soil is marked with symbols consisting of two small letters, which are written in front of the principal fraction: saGr - sandy gravel, siGr - silty gravel, clGr - clayey gravel, grSa - gravelly sand, siSa - silty sand, clSa - clayey sand.

The second secondary fraction that influences engineering properties of soil is also marked with symbols that consist of two small letters, which are written in front of the first secondary fraction and principal fraction.

Coarse-grained soils are additionally marked to indicate the grading level. Thus, a capital letter is added after the mark denoting the principal fraction:

W - well graded sand or gravel,

M - medium-graded sand or gravel,

$\mathrm{P}$ - poorly graded sand or gravel.

The principal fraction of fine-grained soils is marked with symbols composed of two letters, the first of which is the uppercase letter:
Si - silt,
$\mathrm{Cl}-$ clay,
Or - organic soil.

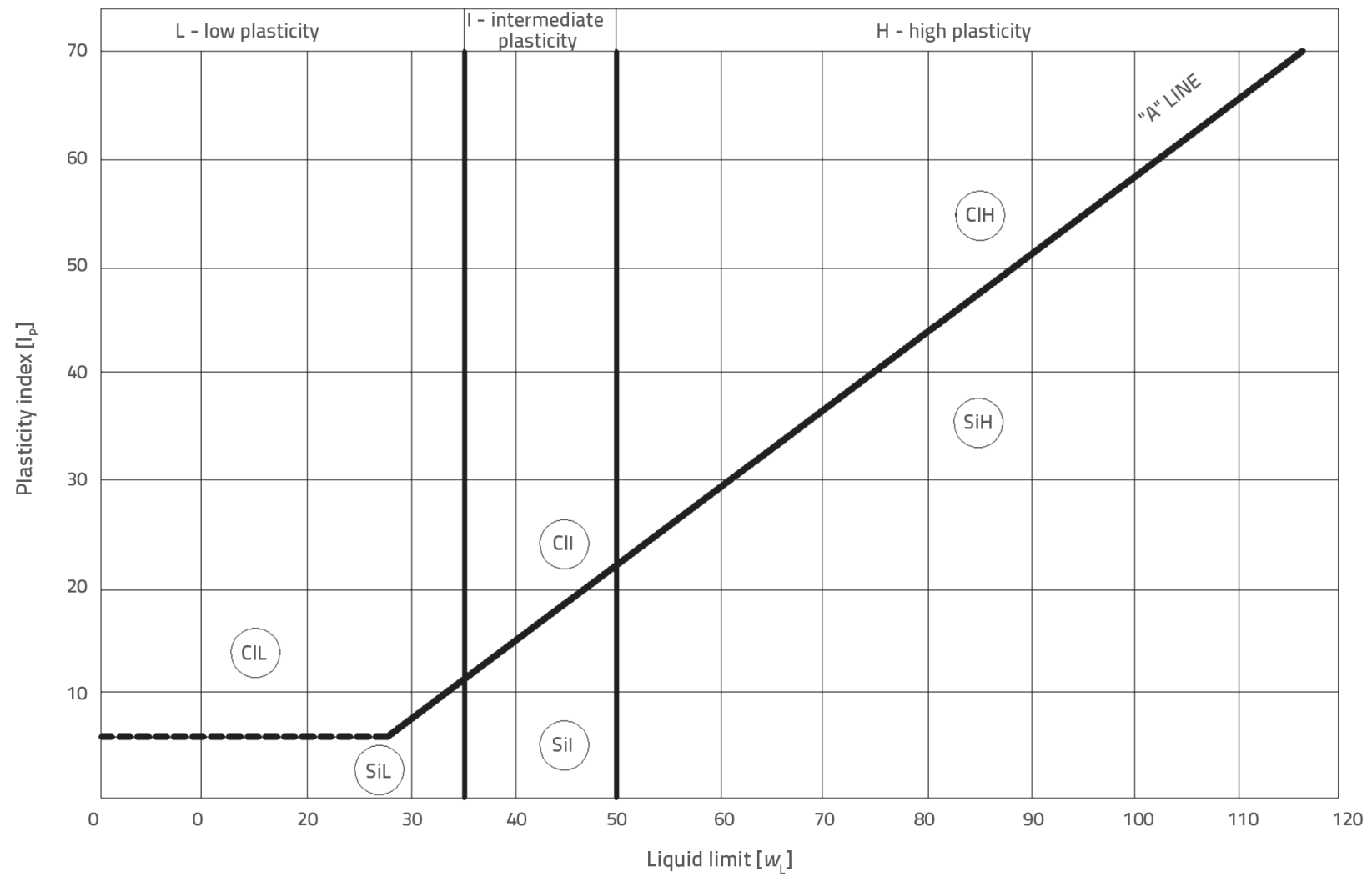

Figure 2. Plasticity diagram for the ESCS classification of soil according to principles set in EN ISO 14688-2 
Table 2. ESCS classification according to principles given in EN ISO 14688-2

\begin{tabular}{|c|c|c|c|c|c|}
\hline \multirow{2}{*}{\multicolumn{4}{|c|}{ Criteria for allocation of symbols and names to individual soil groups based on laboratory testing ${ }^{A}$}} & \multicolumn{2}{|r|}{ Soil classification } \\
\hline & & & & \multirow{2}{*}{$\begin{array}{c}\text { Symbol } \\
\text { GrW }\end{array}$} & \multirow{2}{*}{$\begin{array}{c}\text { Group name }^{\mathrm{B}} \\
\text { Well graded gravel }^{\mathrm{D}}\end{array}$} \\
\hline \multirow{10}{*}{ 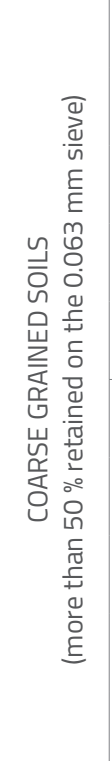 } & \multirow{5}{*}{ 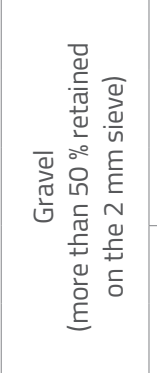 } & \multirow{3}{*}{$\begin{array}{c}\text { Pure gravel } \\
\text { (less than } 5 \% \text { of fine grains }{ }^{\mathrm{E} F} \text { ) }\end{array}$} & $c_{u} \geq 15$ i $1 \leq c_{c} \leq 3^{c}$ & & \\
\hline & & & $6<c_{u}<15 i c_{c}<1^{c}$ & GrM & Medium graded grave $\mathrm{l}^{\mathrm{D}}$ \\
\hline & & & $c_{u}<6$ i/ili $c_{c}<1 c$ & GrP & Poorly graded gravel ${ }^{\mathrm{D}}$ \\
\hline & & \multirow{2}{*}{$\begin{array}{c}\text { Gravel with fine grains } \\
\text { (more than } 15 \% \text { of fine } \\
\text { grains }{ }^{\mathrm{E}, \mathrm{F}} \text { ) }\end{array}$} & Fine grains are classified as siL, sil or siH & siGr & Silty gravel ${ }^{D}$ \\
\hline & & & Fine grains are classified as $\mathrm{clL}, \mathrm{cll}$ or $\mathrm{clH}$ & $\mathrm{clGr}$ & Clayey gravel $^{\mathrm{D}}$ \\
\hline & \multirow{5}{*}{ 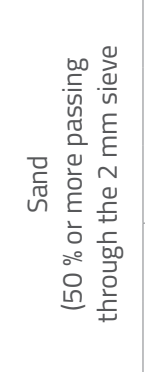 } & \multirow{3}{*}{$\begin{array}{c}\text { Pure sand } \\
\text { (less than } 15 \% \text { of fine grains }{ }^{\mathrm{F}, \mathrm{H}} \text { ) }\end{array}$} & $c_{u} \geq 15$ i $1 \leq c_{c} \leq 3^{c}$ & SaW & Well graded sand $G$ \\
\hline & & & $6<c_{u}<15 i c_{c}<1 c$ & SaM & Medium graded sand ${ }^{G}$ \\
\hline & & & $c_{u}<6$ i/ili $c_{c}<1^{c}$ & $\mathrm{SaP}$ & Poorly graded sand \\
\hline & & \multirow{2}{*}{$\begin{array}{l}\text { Sand with small grains } \\
\text { (more than } 15 \% \text { fine grains }{ }^{F, H} \text { ) }\end{array}$} & Fine grains are classified as siL, sil ili siH & siSa & Silty sand ${ }^{G}$ \\
\hline & & & Fine grains are classified as clL, cll ili clH & $\mathrm{clSa}$ & Clayey sand ${ }^{G}$ \\
\hline \multirow{6}{*}{ 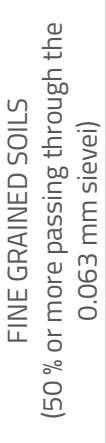 } & \multirow{2}{*}{ 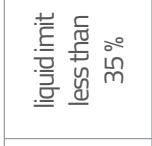 } & \multirow{2}{*}{ Inorganic ${ }^{F}$} & At or above $A$ line & $\mathrm{CIL}$ & Low plasticity clay' \\
\hline & & & Below A line & SiL & Low plasticity silt' \\
\hline & \multirow{2}{*}{ 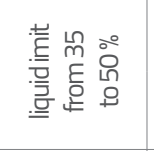 } & \multirow{2}{*}{ Inorganic ${ }^{F}$} & At or above $A$ line & Cll & Medium plasticity clay' \\
\hline & & & Below A line & Sil & Medium plasticity silt' \\
\hline & \multirow{2}{*}{ 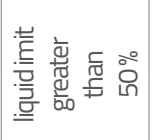 } & \multirow{2}{*}{ Inorganic ${ }^{\mathrm{F}}$} & At or above $A$ line & $\mathrm{ClH}$ & High plasticity clay' \\
\hline & & & Below A line & $\mathrm{SiH}$ & High plasticity silt' \\
\hline \multicolumn{2}{|c|}{ ORGANIC SOIL } & \multicolumn{2}{|c|}{ Primary organic matter, dark colour, and organic odour } & Or & Organic soil \\
\hline \multicolumn{6}{|c|}{ 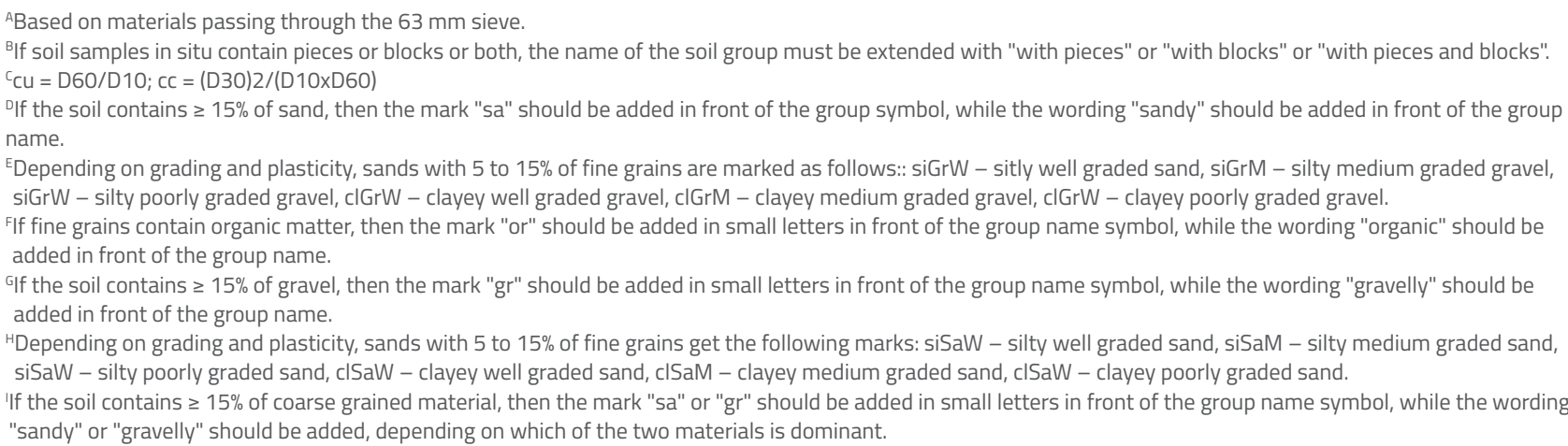 } \\
\hline
\end{tabular}

The secondary fraction that mostly influences engineering properties of soil is marked with symbols consisting of two small letters, which are written in front of the principal fraction: grSi - gravelly silt, saSi - sandy silt, cISi - clayey silt, orSi organic silt,
grCl - gravelly clay, saCl - sandy clay, siCl - silty clay, orCl organic clay,

saOr - sandy organic soil, siOr - silty organic soil, clOr - clayey organic soil.

The second secondary fraction that influences engineering properties of soil is also marked with symbols that consist 
of two small letters, which are written in front of the first secondary fraction and principal fraction.

Fine-grained soils are additionally marked to indicate plasticity. Thus, a capital letter is added after the mark denoting the principal fraction:

$\mathrm{L}$ - low plasticity,

I - meidum plasticity,

$\mathrm{H}$ - high plasticity.

The ESCS classification of soil according to principles given in EN ISO $14688-2$ is presented in Table 2. In addition to Table 2, the plasticity diagram shown in Figure 2 is also used for the ESCS classification of soil.

\subsection{Procedure for ESCS classification of soil according to principles given in EN ISO 14688-2}

\subsubsection{Procedure for preliminary classification of soil}

1. The soil is classified as coarse-grained (incoherent soil) if more than $50 \%$ of the total quantity of dry sample is retained on the $0.063 \mathrm{~mm}$ sieve.

2. The soil is classified as fine-grained (coherent soil) if more than $50 \%$ of the total quantity of dry sample passes through the $0.063 \mathrm{~mm}$ sieve.

\subsubsection{Procedure for classification of coarse-grained soil}

3. The soil is classified as gravel if more than $50 \%$ of the total mass of dry sample is retained on the $2 \mathrm{~mm}$ sieve (including the $0.063 \mathrm{~mm}$ sieve).

4. The soil is classified as sand if $50 \%$ or more of the total mass of dry sample passes through the $2 \mathrm{~mm}$ sieve (including the $0.063 \mathrm{~mm}$ sieve).

5. If less than $5 \%$ of the sample mass passes through the $0.063 \mathrm{~mm}$ sieve, then the coefficient of uniformity $c_{u}$ and the coefficient of curvature $c_{c}$ must be calculated from the grain size distribution curve.

5.1 If the coefficient of uniformity $c_{u}$ is equal to or greater than 15, and if the curvature coefficient is equal to 1 and not greater than 3 , the soil is classified as well graded gravel, GW, or as the well graded sand, SW.

5.2 If the coefficient of uniformity $c_{u}$ is greater than 6 and smaller than 15 , and if the curvature coefficient $c_{c}$ is smaller than 1, the soil is classified as medium graded gravel, GrM, or as medium graded sand, SaM.

5.3 If coefficients of uniformity and curvature do not meet criteria for well or medium graded soil, the soil is classified as a poorly graded gravel, GrP, or as a poorly graded sand, SaP.

6. If more than $15 \%$ of the sample mass passes through the $0.063 \mathrm{~mm}$ sieve, the soil is considered to be a coarse-grained material with fine grains. At that, it should be established whether fine grains are clay or silt, which is determined from the plasticity diagram using the plasticity index and liquid limit.
6.1 The soil is classified as clayey gravel, clGr, or clayey sand, $\mathrm{ClSa}$, if the pair of values $\left(w_{L^{\prime}} I_{p}\right)$ in the plasticity diagram is situated at or above the $A$ line.

6.2 The soil is classified as silty gravel, siGr, or silty sand, siSa, if the pair of values $\left(w_{L^{\prime}} I_{p}\right)$ in the plasticity diagram is situated below the $A$ line.

7. If 5 to $12 \%$ of fine soil grains pass through the $0.063 \mathrm{~mm}$ sieve, then the coefficient of uniformity, $\mathrm{c}_{\mathrm{u}^{\prime}}$ and the coefficient of curvature, $c_{c^{\prime}}$ must be calculated from the grading curve. At that, it should be established whether fine grains are clay or silt particles, which is determined from the plasticity diagram using the plasticity index and liquid limit.

7.1 If the coefficient of uniformity $c_{u}$ is equal to or greater than 15 , and if the coefficient of curvature $c_{c}$ is equal to 1 but not greater than 3 , and if the pair of values $\left(w_{l^{\prime}} I_{p}\right)$ in the plasticity diagram is situated at or above the $A$ line, the soil is classified as a well graded clayey gravel, clGrW, or as a well graded clayey sand, clSaW.

7.2 If the coefficient of uniformity $c_{u}$ is equal to or greater than 15 , and if the coefficient of curvature $c_{c}$ is equal to 1 but not greater than 3 , and if the pair of values $\left(w_{L^{\prime}} I_{P}\right)$ in the plasticity diagram is situated below the $A$ line, the soil is classified as a well graded silty gravel, siGrW, or as a well graded silty sand, siSaW.

7.3 If the coefficient of uniformity $c_{u}$ is greater than 6 and smaller than 15 , and if the coefficient of curvature $c_{c}$ is smaller than 1 , and if the pair of values $\left(w_{L^{\prime}} I_{P}\right)$ in the plasticity diagram is situated at or above the $A$ line, the soil is classified as a medium graded clayey gravel, clGrM, or as a medium graded clayey sand, cISaM.

7.4 If the coefficient of uniformity $c_{u}$ is greater than 6 and smaller than 15 , and if the coefficient of curvature $c_{c}$ is smaller than 1 , and if the pair of values $\left(w_{L^{\prime}} I_{p}\right)$ in the plasticity diagram is situated below the $A$ line, the soil is classified as a medium graded silty gravel, siGrM, or as a medium graded silty sand, siSaM.

7.5 If the coefficients of uniformity and curvature do not meet the criteria for well or medium graded soils, and if the pair of values $\left(w_{L^{\prime}} I_{P}\right)$ in the plasticity diagram is situated at or above the $A$ line, the soil is classified as a poorly graded clayey gravel, clGrP, or as a poorly graded clayey sand, clSaP.

7.6 If the coefficients of uniformity and curvature do not meet the criteria for well or medium graded soils, and if the pair of values $\left(w_{L^{\prime}} I_{p}\right)$ in the plasticity diagram is situated below the $A$ line, the soil is classified as a poorly graded silty gravel, siGrP, or as a poorly graded silty sand, siSaM.

8. If the sand or gravel is dominant in the total mass of the soil sample, and if it contains $15 \%$ or more of some other coarsegrained material, then the mark "sa" or "gr" should be added in small letters in front of the group name symbol, while the wording "sandy" or "gravelly" should be added in front of the group name. For instance, saGrW - sandy well graded gravel, grSaM - gravelly medium graded sand, sasiGr - sandy silty gravel. 
9. If fine grains contain organic matter, the mark "or" should be added in front of the group name symbol, and the wording "organic" should be added in front of the group name. For instance, orSaP - organic poorly graded sand, orclSa organic clayey sand, orsaGrW - organic well graded sandy gravel.

10. If the soil sample in situ contains pieces or blocks or both pieces and blocks, then this situation should be described by adding the wording "with pieces or blocks or with both" to the soil group name.

\subsubsection{Procedure for classification of fine-grained soil}

11. The soil is considered to be clay if the pair of values $\left(w_{l}, I_{p}\right)$ in the plasticity diagram is situated at or above the $A$ line.

11.1 The soil is classified as low plasticity clay, $\mathrm{CIL}$, if the liquid limit is smaller than $35 \%$.

11.2 The soil is classified as intermediate plasticity clay, CII, if the liquid limit is higher than or equal to $35 \%$ and if it is smaller than $50 \%$.

11.3 The soil is classified as high plasticity clay, $\mathrm{ClH}$, if the liquid limit is higher than or equal to $50 \%$.

12. The soil is considered to be silt if the pair of values $\left(w_{L^{\prime}} I_{P}\right)$ in the plasticity diagram is situated below the $A$ line.

12.1 The soil is classified as low plasticity silt, SiL, if the liquid limit is smaller than $35 \%$.

12.2 The soil is classified as intermediate plasticity silt, Sil, if the liquid limit is higher than or equal to $35 \%$ and if it is smaller than $50 \%$.

12.3 The soil is classified as high plasticity silt, $\mathrm{SIH}$, if the liquid limit is higher than or equal to $50 \%$.

13. If $15 \%$ or more of the total quantity of sample is retained at the $0.063 \mathrm{~mm}$ sieve, then the mark "sa" or "gr" should be added in small letters in front of the group name symbol, while the wording "sandy" or "gravelly" should be added in front of the group name, depending on which of the two materials is dominant. If both materials are similarly represented, then the advantage should be given to sand. For instance, saClH - sandy high plasticity clay, grSIL gravelly low plasticity silt.

14. If fine grains contain organic matter, then the mark "or" should be added in small letters in front of the group name symbol, while the wording "organic" should be added in front of the group name. For instance, orSil - organic intermediate plasticity silt, orClH - organic highly plastic clay, orsaSiL - organic sandy low plasticity silt.

\section{Examples of comparison of ESCS classification with USCS classification}

Classification examples for coarse-grained and fine-grained soils are presented in to facilitate transition from the USCS classification of soil according to ASTM D 2487 to the ESCS classification according to principles set in EN ISO 14688-2, and to place emphasis on differences in classification results. For comparison purposes, it was assumed that the same material passage percentages were obtained at the corresponding sieves which separate, according to different standards, sand from gravel, and coarse-grained materials from fine-grained materials.

\section{Example 1}

The following results were obtained by sieving:

Percent passing through the 3 -in $(75 \mathrm{~mm}$ ) sieve, i.e. through the $63 \mathrm{~mm}$ sieve is $100 \%$.

Percent passing through the sieve No. $4(4.75 \mathrm{~mm})$, i.e. through the $2 \mathrm{~mm}$ sieve is $98 \%$.

Percent passing through the sieve No. 200 (0.075 mm), i.e. through the $0.063 \mathrm{~mm}$ sieve is $34 \%$.

Liquid limit and plasticlity limit amount to $w_{L}=38 \%$ i $w_{p}=26 \%$, respectively.

\section{Solution:}

As $100-34=66 \%$ of material was retained at the sieve No. $200(0.075 \mathrm{~mm})$ i.e. at the $0.063 \mathrm{~mm}$ sieve, which is more than $50 \%$ percent of the total soil mass, this is a coarse-grained soil. As $66-2=64 \%$ of material passed through the sieve No. 4 $(4.75 \mathrm{~mm})$ i.e. through the $2 \mathrm{~mm}$ sieve, which is more than 50 $\%$ percent of the coarse-grained material $(66 / 2=33 \%)$, this material is sand.

As more than $15 \%$ of the sample mass passed through the sieve No. 200 (0.075 mm) i.e. through the $0.063 \mathrm{~mm}$ sieve (34 $\%)$, the soil is considered to be a coarse-grained material with fine grains. The plasticity index amounts to $I_{P}=w_{L}-w_{P}=38-$ $26=12 \%$.

As the values of pairs $\left(w_{L^{\prime}} I_{p}\right)$ presented in figures 1 and 2 are below the $A$ line, the soil is classified as silt.

As the gravel percentage is $2 \%$, which is less than $15 \%$, the quantity of gravel does not influence the soil group name.

According to the USCS classification, the soil is classified as "silty sand" and is marked as SM.

According to the ESCS classification, the soil is classified as "silty sand" and is marked as siSa.

\section{Example 2}

The following results were obtained by sieving:

Percent passing through the 3 -in $(75 \mathrm{~mm})$ sieve, i.e. through the $63 \mathrm{~mm}$ sieve is $100 \%$.

Percent passing through the sieve No. $4(4.75 \mathrm{~mm})$, i.e. through the $2 \mathrm{~mm}$ sieve is $100 \%$.

Percent passing through the sieve No. 200 (0.075 mm), i.e. through the $0.063 \mathrm{~mm}$ sieve is $58 \%$.

Liquid limit and plasticlity limit amount to $w_{L}=49 \%$ i $w_{p}=28 \%$, respectively.

\section{Solution:}

As $58 \%$ of material passed through the sieve No. 20010.075 $\mathrm{mm}$ ) i.e. through the $0.063 \mathrm{~mm}$ sieve, which is more than $50 \%$ of the total soil mass, this is a fine-grained soil. 
The liquid limit $w_{L}$ is greater than $35 \%$, and smaller than $50 \%$. The plasticity index amounts to $I_{p}=w_{L}-w_{P}=49-28=21 \%$. As the values of pairs $\left(w_{L^{\prime}} I_{p}\right)$ presented in figures 1 and 2 are below the $A$ line, the soil is classified as silt.

As more than $30 \%$ of the total quantity of sample $(100-58=$ $42 \%$ ) was retained at the sieve No. 200, i.e. at the $0.063 \mathrm{~mm}$ sieve, and as the gravel content is $0 \%$, the sand is dominant, and so the wording "sandy" is added to the group symbol.

According to the USCS classification, the soil is classified as "sandy silt" and is marked as ML.

According to the ESCS classification, the soil is classified as "sandy intermediate plasticity silt" and is marked as saSiM.

\section{Conclusion}

The soil classification conducted for civil engineering purposes enables engineers in all countries of the world to study and understand soil test results in an easier way, while also facilitating communication between engineers and comparison of results obtained in different laboratories. The ISO and CEN have developed standards for the description and identification of soil, EN ISO 14688-1, and soil classification principles EN ISO
14688-2, which, according to the soil marking method, differ considerably from the formerly used national classifications, and from the most frequently used USCS classification, from which all national classifications have in fact originated. So far, 34 European countries, including Croatia, assumed the obligation, as CEN members, to accept and implement European standards through their national standardisation bodies.

In order to enable transfer to the new soil marking method, and taking into account soil classification principles set to this effect, this paper proposes a comprehensive ESCS classification of soil which enables practical engineers to classify soil in compliance with the adopted European standards. The procedure for using the ESCS classification is also presented, and examples of comparison of soil classification results with the USCS classification are given. The examples presented in the paper show that soil classification procedures are quite similar, as the ESCS classification generally follows guidelines defined by the USCS classification according to ASTM D 2487, as well as the soil classification principles according to European standard EN ISO 14688-2, and this all the way to the soil group names, where soil group names partly differ, while the symbols are completely different.

\section{REFERENCES}

[1] Child, G.H.: Soil descriptions - Quo Vadis?, Site Investigation Practice: Assessing BS 5930, ed. Hawkins A.B., Eng. Geol. Special Pub. No. 2, Geological Society, pp. 73-81, 1986.

[2] Atterberg, A.: Die rationale Klassifikation der Sande und Kiese, Chem. Ztg., 29, pp. 195-198, 1905.

[3] Atterberg, A.: Die Konsistenz und die Bindigheit der Boden, Int. Mitt. Bodenkunde., 2, pp. 148-189, 1912.

[4] Soil Survey Staff: Soil Survey Manual, U.S. Dep. Agric. Handb., vol. 18, 503 pp., U.S. Gov. Print. Off., Washington, D. C. 1951.

[5] Davis, R. O. E., Bennet, H.H.:, Grouping of soils on the basis of mechanical analysis, Dep. Circ. 419, U.S. Dep. of Agric., Washington, D. C. 1927.

[6] Casagrande, A.: Classification and identification of soils, Proc. ASCE, 73 (6), pp. 783-810, 1947.

[7] ASTM D2487-11: Standard Practice for Classification of Soils for Engineering Purposes (Unified Soil Classification System). ASTM International, West Conshohocken, PA, 2011.

[8] Dumbleton, M.J.: The classification and description of soils for engineering purposes: a suggested revision of the British system, Ministry of Transport, RRL Report LR 182, Road Research Laboratory, Crowthorne, Berks. 1968.

[9] Dumbleton, M.J.: The British soil classification system for engineering purposes: its development and relation to other comparable systems, TRRL Report LR 1030, Transport and Road Research Laboratory, Crowthorne, Berks. 1981.

[10] BS 5930:1990: British Standard. Code of practice for site investigations. British Standards Institute, London, 1990.

[11] DIN 18196:2011-05: Erd - und Grundbau - Bodenklassifikation für bautechnishe Zwecke. Beuth Verlag GmbH. Berlin, 2011.

[12] EN ISO 14688-1:2002: Geotechnical investigation and testing Identification and classification of soil - Part 1: Identification and description. Comité Européen de Normalisation. Brussels, 2002.

[13] EN ISO 14688-1:2002/A1:2013: Geotechnical investigation and testing - Identification and classification of soil - Part 1: Identification and description-Amendment 1. Comité Européen de Normalisation. Brussels, 2013.

[14] EN ISO 14688-2:2004: Geotechnical investigation and testing - Identification and classification of soil - Part 2: Principles for a classification. Comité Européen de Normalisation.Brussels, 2004.

[15] EN ISO 14688-2:2004/A1:2013: Geotechnical investigation and testing - Identification and classification of soil - Part 2: Principles for a classification - Amednment 1. Comité Européen de Normalisation. Brussels, 2004

[16] HRN EN ISO 14688-1:2008 en: Geotehničko istraživanje i ispitivanje - Identifikacija i klasifikacija tla - 1. dio: Identifikacija i opis. Zagreb, Hrvatski zavod za norme. 2008.

[17] HRN EN ISO 14688-2:2008 en: Geotehničko istraživanje i ispitivanje - Identifikacija i klasifikacija tla - 2. dio: Načela klasifikacije. Zagreb, Hrvatski zavod za norme. 2008.

[18] HRN EN ISO 14688-1:2008/A1:2013 en: Geotehničko istraživanje i ispitivanje - Identifikacija i klasifikacija tla - 1. dio: Identifikacija i opis - Amandman 1. Zagreb, Hrvatski zavod za norme. 2013.

[19] HRN EN ISO 14688-2:2008/A1;2013 en: Geotehničko istraživanje i ispitivanje - Identifikacija i klasifikacija tla - 2. dio: Načela klasifikacije - Amandman 2. Zagreb, Hrvatski zavod za norme. 2013. 